\title{
Partial characterization of specific inducers of a cuticle-degrading protease from the insect pathogenic fungus Metarhizium anisopliae
}

\author{
Ian C. Paterson, A. Keith Charnley, Richard M. Cooper \\ and John M. Clarkson
}

Author for correspondence: John M. Clarkson. Tel: +44225 826826. Fax: +44225826779

Microbial Pathogenicity Group, School of Biological Sciences, University of Bath, Bath BA2 7AY, UK

\begin{abstract}
The insect pathogenic fungus Metarhizium anisopliae produces several extracellular cuticle-degrading proteases and evidence is consistent with one of these, PR1, which is a chymoelastase, being a determinant of pathogenicity. We have shown previously that PR1 production is regulated by both carbon catabolite and nitrogen metabolite repression and also by specific induction under derepressed conditions by insect cuticle. In the present work we have established that an enzymically released proteinaceous component(s) of insect cuticle is capable of inducing PR1 (based on appearance of extracellular activity). Cuticle of the desert locust Schistocerca gregaria treated with KOH to remove protein failed to induce PR1 production, whereas cuticle treated with either chloroform or ether to remove lipids still induced PR1. Cuticle digested with either PR1 or the trypsin-like PR2 of $M$. anisopliae released peptides mainly in the range 150-2000 Da; addition of these peptides generated by PR1 or PR2 at $3 \mu \mathrm{g}$ alanine equivalents $\mathrm{ml}^{-1}$ induced PR1 production to a level similar $(75 \%)$ to that obtained with untreated insect cuticle. Several amino acids and peptides which are abundant in insect cuticular protein (Ala, Gly, Ala-Ala, Ala-Ala-Ala, Ala-Pro and Pro-Ala) were tested at a range of concentrations and in restricted cultures for their ability to induce PR1. None induced the protease to the levels seen with cuticle or peptides enzymically released from cuticle, although some dimers and notably the monomers Ala and Gly gave 2-2.7-fold enhanced PR1 activity above derepressed basal levels (up to $48-57 \%$ of that achieved with induced synthesis on cuticle). There was evidence for more efficient uptake and/or catabolism by $\mathbf{M}$. anisopliae of alanine di- and tripeptides than of monomer amino acids.
\end{abstract}

Keywords: Metarbizium anisopliae, insect pathogen, protease regulation

\section{INTRODUCTION}

Infection of insects by the filamentous Deuteromycete fungus Metarbizium anisopliae occurs by penetration of the cuticle by a combination of mechanical pressure and enzymic degradation (Charnley, 1984). M. anisopliae produces a range of extracellular enzymes, namely proteases, chitinases and esterases, that are active against the major components of insect cuticle (Charnley \& St Leger, 1991). Three endoproteases, chymoelastase (PR1), trypsin-like protease (PR2) and trypsin-like cysteine protease (PR4) have been characterized (St Leger et al., 1987a ; Cole et al.,

Abbreviation: NA, nitroanilide.
1993). Several lines of evidence indicate that PR 1 is essential for cuticle penetration (St Leger et al., 1987b, 1988a) but the roles of PR2 and PR4 are unclear.

As with many other fungal proteases, PR1 and PR2 are controlled by multiple regulatory circuits which include carbon and nitrogen derepression (St Leger et al., 1988b) and induction (Paterson et al., 1993, 1994). It has been demonstrated that the regulation of PR1 by derepression is achieved at the level of transcription (St Leger $e t$ al., 1991). Under derepressed conditions, PR2 is induced by a range of proteinaceous substrates (Paterson et al., 1993) whereas PR1 is specifically induced by a component of insect cuticle (Paterson et al., 1994). This is the first example of specific induction of any microbial protease 
and presumably reflects the adaptation of $M$. anisopliae to insect parasitism. Insect cuticle is composed of two layers, the outer epicuticle and the procuticle. The epicuticle is a very complex, thin composite structure which is devoid of chitin but contains phenol-stabilized protein (Andersen, 1979). The procuticle constitutes the majority of the cuticle and comprises chitin fibrils embedded in a protein matrix, together with lipids and quinones. In insects such as locusts, the procuticle may be further differentiated into an outer exocuticle, in which the protein is stabilized (sclerotized) by quinone cross-links, and an inner endocuticle which is unsclerotized. Protein can contribute as much as $70 \%$ of the cuticle, with chitin content usually between 20 and $50 \%$. It is therefore likely that PR 1 is induced by either the lipid, the protein or the chitin component of cuticle. The exact nature of the inducing molecule(s) has yet to be identified. We report here that an enzymically released proteinaceous component of insect cuticle is capable of inducing PR1.

\section{METHODS}

Culture conditions. The fungal isolate ME1, media and culture conditions, and the preparation of insect cuticle have been described previously (Paterson et al., 1993, 1994). Carbon sources were supplied to cultures at $1 \%(\mathrm{w} / \mathrm{v})$ unless otherwise stated. For certain experiments, amino acid monomers and dimers were also supplied at linear low rates in a restricted manner by means of diffusion capsules (Pirt, 1971; Cooper \& Wood, 1975). Rates were controlled by altering the number of membranes (dialysis tubing) through which diffusion occurred. Capsules containing alanine $(10 \%, \mathrm{w} / \mathrm{v})$ and three membranes, or alanine dimers $(5 \%, \mathrm{w} / \mathrm{v})$ and one membrane, gave diffusion rates into $100 \mathrm{ml}$ medium of approximately $20 \mu \mathrm{g} \mathrm{ml}^{-1} \mathrm{~h}^{-1}$. Empty diffusion capsules were washed in absolute ethanol and then autoclaved with carbon sources before placing in cultures. Insoluble carbon and nitrogen sources were sterilized in an atmosphere of propylene oxide.

Processing of cuticle. Protein was removed from insect cuticle by hydrolysing powdered cuticle in $30 \%(\mathrm{w} / \mathrm{v}) \mathrm{KOH}$ at $80^{\circ} \mathrm{C}$ for $2 \mathrm{~h}$. The chitinous cuticle, which is resistant to $\mathrm{KOH}$ treatment, was removed from the hydrolysate, then washed extensively in distilled water and dried (Grosscurt, 1978). Hydrocarbons, glycerides and sterol esters were removed from cuticle by stirring powdered cuticle in diethyl ether or chloroform for $2 \mathrm{~h}$ at room temperature. The remaining cuticle was then stirred as above in ethanol to extract phospholipids and fatty acids (Gilby, 1980), then washed in distilled water and dried. Chitin consisted of crab chitin (Sigma) which had been de-proteinated as described above for insect cuticle.

Transfer experiments. Complete medium (Paterson et al., 1993), $100 \mathrm{ml}$ in $250 \mathrm{ml}$ Erlenmeyer flasks, was inoculated with $4 \times 10^{6}$ conidia and incubated at $27^{\circ} \mathrm{C}$ in an orbital shaker (150 r.p.m.) for $3 \mathrm{~d}$ in order to establish extensive fungal growth (about $300 \mathrm{mg}$; Paterson et al., 1994). Cultures developed as uniform submerged mycelial balls with no sporulation evident; the morphology of fungal cultures remained constant over the duration of the experiments. The culture was sieved through two layers of sterile muslin. Retained mycelium was washed with sterile basal salts medium (BSM) (Paterson et al., 1993), transferred to $100 \mathrm{ml} \mathrm{BSM}$, and then incubated for a further $24 \mathrm{~h}$ under the same conditions as above to ensure complete catabolite derepression. Potential inducers of PR 1 were then added and PR1 activity in the culture supernatant was assayed for up to $24 \mathrm{~h}$. The numbers of replicates and experiments are given in Tables $1-3$.

Enzyme assays. PR 1 and PR2 were assayed by monitoring the release of nitroanilide (NA) from the peptide substrates succinylAla-Ala-Pro-Phe-NA and benzoyl-Phe-Val-Arg-NA, respectively, as previously described (Paterson et al., 1993, 1994).

Chemicals. All chemicals, unless otherwise stated, were from Sigma. HPLC grade solvents were from Rathburns.

HPLC. All HPLC was performed as described by Paterson et al. (1994) except that the injection valve was fitted with either a 20 or $100 \mu$ l loop.

Enzyme purification. Prior to enzyme purification, culture filtrates were reduced in volume about 100 -fold by ultrafiltration on YM5 membranes (Amicon; $5 \mathrm{kDa}$ exclusion). PR1 was purified by cation-exchange HPLC. Separation was performed on a Dynamax SCX-i (Rainin) strong cation-exchange column $(4.6 \mathrm{~mm} \times 10 \mathrm{~cm})$ equilibrated with $20 \mathrm{mM}$ sodium acetate pH $5.5\left(1 \mathrm{ml} \mathrm{min}^{-1}\right)$. Elution of basic proteins was achieved with a linear gradient $(0-0.4 \mathrm{M} \mathrm{NaCl})$ in similar buffer with detection at $280 \mathrm{~nm}$. The majority of the proteins did not bind to the column; PR1 and its pro-enzyme (S. C. J. Cole, R. M. Cooper \& A. K. Charnley, unpublished) were usually the only proteins eluted by the gradient.

PR2 was purified by anion-exchange chromatography on a column $(10 \times 1 \mathrm{~cm})$ of Q-Sepharose equilibrated in $10 \mathrm{mM}$ Tris/ $\mathrm{HCl} \mathrm{pH} 8$. Prior to loading the sample, the column was washed with $30 \mathrm{ml}$ equilibration buffer and the proteins then eluted with a linear $60 \mathrm{ml}$ Tris $/ \mathrm{HCl}$ gradient $(0.01-0.75 \mathrm{M})$.

After purification, both enzymes were pure as demonstrated by single bands on SDS-PAGE and had the same molecular mass and substrate specificities as described by St Leger et al. (1987a).

Hydrolysis and separation of cuticular peptides. One gram of cuticle was digested in $100 \mathrm{ml}$ buffered BSM (Paterson et al., 1993) containing $1 \mathrm{mg}$ purified PR 1 or PR $2 \mathrm{ml}^{-1}$ and incubated at $27^{\circ} \mathrm{C}, 150$ r.p.m. for 24 h. The same conditions were used to solubilize peptides with buffer without the addition of enzyme. The products were analysed by HPLC using an Anagel TSK 3000 SWXL gel filtration column $(7.8 \mathrm{~mm} \times 30 \mathrm{~cm})$. The mobile phase was $0.1 \mathrm{M} \mathrm{Na}_{2} \mathrm{SO}_{4}$ in $0.1 \mathrm{M}$ sodium phosphate buffer, $\mathrm{pH} 7 \cdot 5$, with a flow rate of $0 \cdot 8 \mathrm{ml} \mathrm{min}{ }^{-1}$ and detection at $280 \mathrm{~nm}$. The column was calibrated with L-phenylalanine, L-alanyl-Lproline, glutathione and insulin A (molecular mass 165, 186, 307 and $2531 \mathrm{Da}$, respectively).

\section{RESULTS}

\section{Cuticle components as inducers of PR1 production}

In view of the structure of insect cuticle it is likely that PR1 is induced by either the lipid, the protein or the chitin component. To test this hypothesis, cuticle, modified cuticle or cuticle components were added to cultures starved of $\mathrm{C}$ and $\mathrm{N}$ for $24 \mathrm{~h}$; PR1 activity was then measured after 4 and $12 \mathrm{~h}$ (Table 1 ). The treatments were: deproteinated chitin; deproteinated (by $\mathrm{KOH}$ ) cuticle; and cuticle extracted with ether or with chloroform (to remove the lipid components).

Ether- or chloroform-extracted cuticle induced PR1 production to a level similar to that with untreated cuticle, 
Table 1. PR1 induction in M. anisopliae by components of insect cuticle

\begin{tabular}{|c|c|c|}
\hline \multirow[t]{2}{*}{$\mathrm{C} / \mathrm{N}$ source $(1 \%, \mathrm{w} / \mathrm{v})$} & \multicolumn{2}{|c|}{ Enzyme activity* } \\
\hline & $4 \mathrm{~h}$ & $12 \mathrm{~h}$ \\
\hline Control $(-\mathrm{C},-\mathrm{N})$ & $181 \cdot 8 \pm 6 \cdot 9$ & $290 \cdot 9 \pm 3.7$ \\
\hline Cuticle & $738 \cdot 6 \pm 21 \cdot 5$ & $2551 \cdot 6 \pm 58 \cdot 9$ \\
\hline Ether-extracted cuticle & $545 \cdot 5 \pm 19 \cdot 4$ & $2863 \cdot 7 \pm 80 \cdot 3$ \\
\hline $\mathrm{KOH}$-extracted cuticle & $252 \cdot 3 \pm 11 \cdot 5$ & $593 \cdot 2 \pm 30 \cdot 8$ \\
\hline $\begin{array}{l}\text { Chloroform-extracted } \\
\text { cuticle }\end{array}$ & $637 \cdot 5 \pm 17 \cdot 4$ & $2687 \cdot 7 \pm 61 \cdot 7$ \\
\hline Chitin & $418 \cdot 0 \pm 26 \cdot 1$ & $711 \cdot 4 \pm 22 \cdot 9$ \\
\hline
\end{tabular}

* Mean activity $\pm S D$ from three replicates $4 \mathrm{~h}$ and $12 \mathrm{~h}$ after the addition of potential inducers to cultures starved of $\mathrm{C}$ and $\mathrm{N}$ $(-\mathrm{C},-\mathrm{N})$ for $24 \mathrm{~h}$. Enzyme activity is expressed as nmol $\mathrm{NA} \mathrm{m}{ }^{-1} \mathrm{~min}^{-1}$ released from succinyl-(Ala $)_{2}$-Pro-Phe-NA. The results are representative of three similar experiments.

suggesting that cuticular lipids do not affect PR1 production (Table 1 ). Activity with chitin was nearly $2 \cdot 5$ times that of controls lacking $\mathrm{C}$ and $\mathrm{N}(-\mathrm{C},-\mathrm{N})$ but activities after $12 \mathrm{~h}$ were only about $30 \%$ of those with cuticle. It is possible that chitin was utilized as a source of $\mathrm{C}$ and $\mathrm{N}$, enabling slightly enhanced PR1 production without causing catabolite repression. Deproteinized cuticle also failed to induce PR1 and resulted in levels of activity similar to those with chitin. These results imply

Table 2. Effect of peptides solubilized from insect cuticle on PR1 production by M. anisopliae

\begin{tabular}{|c|c|c|c|}
\hline \multirow[t]{2}{*}{$\mathrm{C} / \mathrm{N}$ source } & \multirow{2}{*}{$\begin{array}{c}\text { Concn } \\
\left(\mu \mathrm{g} \mathrm{ml}^{-1}\right)\end{array}$} & \multicolumn{2}{|c|}{ Enzyme activity* } \\
\hline & & $4 \mathrm{~h}$ & $8 \mathrm{~h}$ \\
\hline $\begin{array}{l}\text { Controls } \\
-\mathrm{C},-\mathrm{N}\end{array}$ & & $185 \cdot 4 \pm 16 \cdot 9$ & $268 \cdot 3 \pm 23 \cdot 4$ \\
\hline Cuticle & $10^{4} \dagger$ & $485 \cdot 7 \pm 49 \cdot 7$ & $1297 \cdot 0 \pm 64 \cdot 5$ \\
\hline PR1 products & $\begin{array}{l}1 \cdot 5 \\
3 \cdot 0 \\
4 \cdot 5\end{array}$ & $\begin{array}{l}375 \cdot 6 \pm 25 \cdot 4 \\
400 \cdot 1 \pm 19 \cdot 2 \\
214 \cdot 4 \pm 11 \cdot 5\end{array}$ & $\begin{array}{l}607 \cdot 4 \pm 39 \cdot 1 \\
818 \cdot 7 \pm 40 \cdot 8 \\
482 \cdot 2 \pm 17 \cdot 6\end{array}$ \\
\hline PR2 products & $\begin{array}{l}1 \cdot 5 \\
3 \cdot 0 \\
4 \cdot 5\end{array}$ & $\begin{array}{l}354 \cdot 6 \pm 17 \cdot 4 \\
427 \cdot 2 \pm 33 \cdot 1 \\
271 \cdot 6 \pm 22 \cdot 6\end{array}$ & $\begin{array}{l}849 \cdot 9 \pm 25 \cdot 9 \\
977 \cdot 2 \pm 63 \cdot 3 \\
662 \cdot 3 \pm 29 \cdot 7\end{array}$ \\
\hline Soluble products & $\begin{array}{l}1 \cdot 5 \\
3 \cdot 0 \\
4 \cdot 5\end{array}$ & $\begin{array}{c}118 \cdot 2 \pm 16 \cdot 4 \\
227 \cdot 2 \pm 17 \cdot 5 \\
97 \cdot 1 \pm 6 \cdot 8\end{array}$ & $\begin{array}{l}374 \cdot 4 \pm 21 \cdot 2 \\
413 \cdot 6 \pm 29 \cdot 7 \\
428 \cdot 1 \pm 27 \cdot 9\end{array}$ \\
\hline
\end{tabular}

* Mean activity $\pm s D$ from three replicates $4 \mathrm{~h}$ and $12 \mathrm{~h}$ after the addition of peptides generated from insect cuticle to cultures starved of $\mathrm{C}$ and $\mathrm{N}(-\mathrm{C},-\mathrm{N})$ for $24 \mathrm{~h}$. Other details as for Table 1.

$+1 \%(w / v)$.
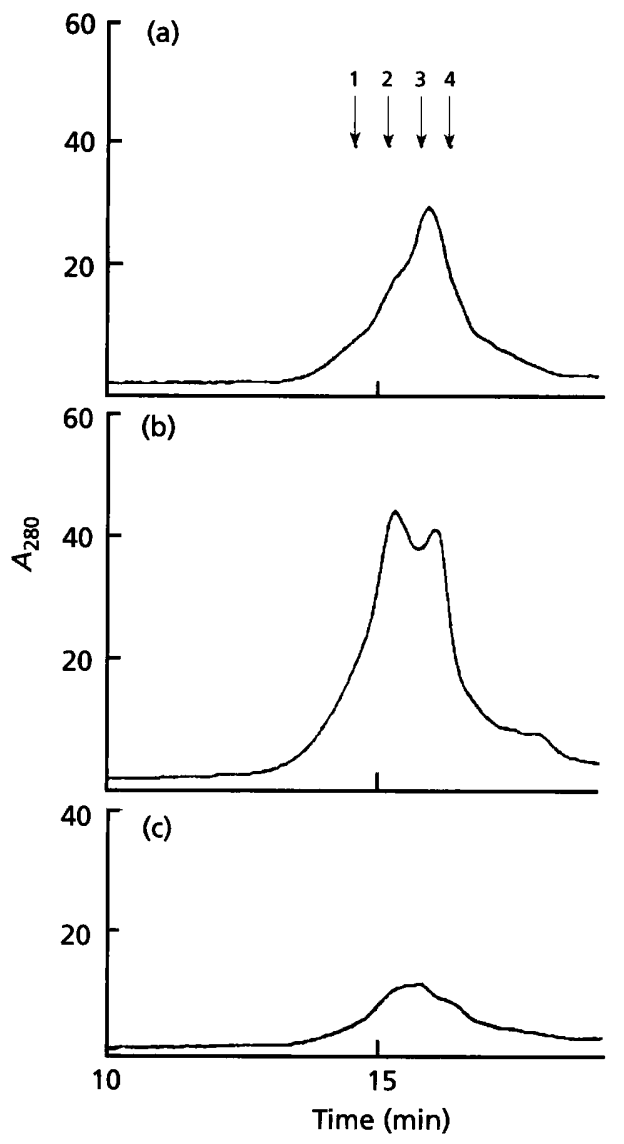

Fig. 1. High performance gel filtration of peptides released by digestion of cuticle by PR1 (a) or PR2 (b), or solubilized by buffer $(c)$. Locust cuticle $(1 \mathrm{~g})$ was incubated with purified PR1 or PR2 $\left(1 \mathrm{mg} \mathrm{ml}^{-1}\right)$ in $100 \mathrm{ml}$ buffered BSM at $27^{\circ} \mathrm{C}, 150$ r.p.m. for $24 \mathrm{~h}$. The same conditions were used to solubilize peptides with buffered BSM only. Peptide products were detected by absorbance at $280 \mathrm{~nm}$ after separation by gel filtration. Molecular mass markers (numbered arrows) are (1) 2531, (2) 307, (3) 186 and (4) $165 \mathrm{Da}$.

that the inducer of PR1 is some component of cuticular protein.

\section{Cuticular protein as an inducer of PR1 production}

Attempts were made to obtain by HPLC the peptides hydrolysed by the two proteases which could function as inducers of PR1 production. PR1 released peptides mainly in the range $150-2000 \mathrm{Da}$, with a predominant peak at approximately $200 \mathrm{Da}$ (Fig. 1a). PR2 generated peptides of a similar size range to PR1 but with a different distribution; peaks were at approximately 300 and $160 \mathrm{Da}$ (Fig. 1b). Some peptides were solubilized in buffer alone; these were in the range 100-300 Da and were released in smaller quantities than that released by enzymic hydrolysis (Fig. 1c). The PR1-, PR2- and buffer-solubilized products contained $24,17.5$ and $9.5 \mu \mathrm{g}$ alanine equivalents $\mathrm{ml}^{-1}$, respectively (assayed by the method of Moore \& Stein, 1948). 
To test the ability of the peptides to induce PR1, mycelium starved of $\mathrm{C}$ and $\mathrm{N}$ as described above was transferred to $100 \mathrm{ml} \mathrm{BSM}$ containing $1 \cdot 5,3$ and $4.5 \mu \mathrm{g}$ alanine equivalents $\mathrm{ml}^{-1}$ of either the PR1-, PR2- or buffer-solubilized peptides. PR 1 activity was assayed after 4 and $8 \mathrm{~h}$ (Table 2).

Addition of peptides generated by PR 1 and PR2 at $3 \mu \mathrm{g}$ alanine equivalents $\mathrm{ml}^{-1}$ induced PR1 production to a level similar to that seen with insect cuticle after $4 \mathrm{~h}$ exposure. After $12 \mathrm{~h}$ incubation, the PR2- and PR1generated peptides induced PR1 production to about $75 \%$ and $63 \%$, respectively, of that in cultures with insect cuticle. Addition of PR1- or PR2-generated peptides at $4.5 \mu \mathrm{g}$ alanine equivalents $\mathrm{ml}^{-1}$ resulted in lower activities compared to those detected at $3 \mu \mathrm{g}$ alanine equivalents $\mathrm{ml}^{-1}$, presumably as a result of catabolite repression.

Addition of buffer-solubilized peptides caused a slight increase in PR1 production which was investigated further. Mycelia starved of $\mathrm{C}$ and $\mathrm{N}$ were transferred to flasks containing $90 \mathrm{ml} \mathrm{BSM}$ plus $10 \mathrm{ml}$ of the digestion products released after 24 h either by enzyme or by buffer. PR1 induction occurred in flasks containing the PR1 products $(85 \%$ of that seen with cuticle after 4 h) or PR2 products ( $81 \%$ of that seen with cuticle after $4 \mathrm{~h}$ ) but with the buffer-solubilized peptides there was only $9 \%$ of the activity seen with cuticle after $4 \mathrm{~h}$ (data not shown). This suggests that PR1 induction is not due to passive release of solubilized peptides, but occurs as a result of protease (PR1 or PR2) action on cuticle proteins.

The profile of hydrolysis products generated from cuticle by PR2 showed two peaks, at approximately 160 and $300 \mathrm{Da}$. A sample of these peptides, equivalent to $87 \cdot 5 \mu \mathrm{g}$ alanine, was separated into two fractions, $<200 \mathrm{Da}$ and $>200 \mathrm{Da}$, and added separately to derepressed mycelium. The fraction of $<200 \mathrm{Da}$ completely repressed PR1 production whilst the fraction $>200 \mathrm{Da}$ induced PR1 to a level similar to that seen with insect cuticle (data not shown).

\section{Potential peptide inducers from insect cuticle}

Abundant amino acids and/or peptide sequences that are unique to and common in host insect cuticle are possible candidates to effect PR1 induction. Alanine is the predominant (about 35\%) amino acid in locust cuticle (St Leger et al., 1986), but comparatively little information is available on the primary structure of cuticular proteins. The N-terminal sequences of eight exocuticle proteins and the entire sequences of seven other exocuticle proteins from Locusta migratoria have been determined (Hojrup et al., 1986a, b; Klarskov et al., 1989; Andersen et al., 1993). In general, the sequences of these proteins are characterized by three types of region: (i) regions enriched in glycine, leucine or tyrosine, (ii) hydrophobic regions with repeats of an Ala-Ala-Pro-Ala/Val motif often preceded by tyrosine, and (iii) hydrophilic regions, dominated by amino acids with relatively large side chains. Only one adult locust endocuticular protein has been sequenced (Talbo et al., 1991); it has sequence similarity with a
Table 3. Effect of potential inducers on $\operatorname{Pr} 1$ production by $M$. anisopliae

\begin{tabular}{|c|c|c|c|}
\hline \multirow[t]{2}{*}{$\mathrm{C} / \mathrm{N}$ source } & \multirow{2}{*}{$\begin{array}{c}\text { Concn } \\
(\%, w / v)\end{array}$} & \multicolumn{2}{|c|}{ Enzyme activity* } \\
\hline & & $4 \mathrm{~h}$ & $12 \mathrm{~h}$ \\
\hline Control $(-\mathrm{C},-\mathrm{N})$ & & $172 \cdot 8 \pm 11 \cdot 4$ & $440 \cdot 6 \pm 19 \cdot 7$ \\
\hline Cuticle & & $620 \cdot 1 \pm 37 \cdot 6$ & $2560 \cdot 9 \pm 69 \cdot 7$ \\
\hline Ala & $t$ & $240.4 \pm 28.6$ & $726 \cdot 7 \pm 35 \cdot 4$ \\
\hline Ala & $0 \cdot 1$ & $221 \cdot 5 \pm 15 \cdot 2$ & $894.7 \pm 41 \cdot 6$ \\
\hline Ala & $0 \cdot 01$ & $243.6 \pm 33.7$ & $897 \cdot 3 \pm 59 \cdot 6$ \\
\hline Gly & $\dagger$ & $309 \cdot 0 \pm 25 \cdot 3$ & $1082 \cdot 8 \pm 75 \cdot 1$ \\
\hline Gly & $0 \cdot 1$ & $314 \cdot 4 \pm 26 \cdot 7$ & $914 \cdot 3 \pm 41 \cdot 8$ \\
\hline Gly & $0 \cdot 01$ & $356 \cdot 1 \pm 31 \cdot 9$ & $1178 \cdot 4 \pm 86 \cdot 2$ \\
\hline $\mathrm{Ala}_{2}$ & $\dagger$ & $218 \cdot 2 \pm 19 \cdot 6$ & $650 \cdot 5 \pm 28 \cdot 5$ \\
\hline $\mathrm{Ala}_{2}$ & $0 \cdot 1$ & 0 & $327 \cdot 5 \pm 22 \cdot 1$ \\
\hline $\mathrm{Ala}_{2}$ & $0 \cdot 01$ & $239 \cdot 3 \pm 24 \cdot 8$ & $761 \cdot 4 \pm 31 \cdot 8$ \\
\hline $\mathrm{Ala}_{3}$ & $0 \cdot 1$ & 0 & $456 \cdot 9 \pm 39 \cdot 7$ \\
\hline $\mathrm{Ala}_{3}$ & 0.01 & $169 \cdot 9 \pm 15 \cdot 6$ & $579 \cdot 7 \pm 23 \cdot 7$ \\
\hline Ala-Pro & $\dagger$ & $277 \cdot 2 \pm 29 \cdot 1$ & $711 \cdot 3 \pm 51 \cdot 7$ \\
\hline Ala-Pro & $0 \cdot 1$ & 0 & $295 \cdot 6 \pm 17 \cdot 9$ \\
\hline Ala-Pro & $0 \cdot 01$ & $354 \cdot 5 \pm 28 \cdot 4$ & $776 \cdot 1 \pm 44 \cdot 4$ \\
\hline Pro-Ala & $t$ & $316 \cdot 8 \pm 32 \cdot 2$ & $652 \cdot 6 \pm 41 \cdot 4$ \\
\hline Pro-Ala & $0 \cdot 1$ & 0 & $314 \cdot 6 \pm 14 \cdot 6$ \\
\hline Pro-Ala & $0 \cdot 01$ & $272 \cdot 7 \pm 21 \cdot 9$ & $698 \cdot 4 \pm 36 \cdot 9$ \\
\hline
\end{tabular}

* Details as for Table 1 .

† Restricted supply from diffusion capsules as described in the text.

number of proteins from soft larval cuticles from Lepidoptera (Rebers \& Riddiford, 1988; Willis, 1987) and Diptera (Snyder et al., 1982; Henzel et al., 1985) but is very different from adult locust exocuticle proteins. In particular there are no repeat motifs of Ala-Ala-Pro-Ala/Val. Since it is most likely that the inducer(s) is a frequently occurring peptide motif, the hypothesis was made that the exocuticle is the source of the inducer(s). We investigated the possibility that either alanine, glycine or one of the repeat peptide motifs (complete or partial) could induce PR1 production.

Mycelia starved of $\mathrm{C}$ and $\mathrm{N}$ for $24 \mathrm{~h}$ as described in Methods were supplied with the potential inducers alanine, glycine, Ala-Ala, Ala-Pro and Pro-Ala at $0 \cdot 1$ and $0.01 \%$, and by means of diffusion capsules. Ala-Ala-Ala was supplied at 0.1 and $0.01 \%$ only. The concentrations of amino acids and peptides were kept low in an attempt to avoid $\mathrm{C}$ and $\mathrm{N}$ repression. The concentration of amino acids detected in culture fluids from cultures containing diffusion capsules was $2.9 \mathrm{\mu g} \mathrm{m}^{-1}$ (equivalent to $0.0029 \%$ ) and $2.3 \mu \mathrm{g} \mathrm{ml}^{-1}$ (equivalent to $0.0023 \%$ ) for alanine and its dimer, respectively, indicating that they were being utilized by the fungus at approximately the rate of diffusion, and were not rising to levels likely to cause catabolic repression. Biomass determinations were not performed because the maximum possible increase with inducers at $0.01 \%$ would represent about $3 \%$ 
increase in dry weight in $4 \mathrm{~h}$ and with diffusion capsules $<3 \%$ in $4 \mathrm{~h}$.

PR1 production under these conditions is summarized in Table 3. Basal synthesis was detected in derepressed $(-\mathrm{C},-\mathrm{N})$ controls, with induced levels on cuticle 3.6and $5 \cdot 8$-fold greater after $4 \mathrm{~h}$ and $12 \mathrm{~h}$, respectively, as reported previously (Paterson et al., 1994). The most notable effects of the potential inducers were seen with glycine and Ala-Pro. After $4 \mathrm{~h}$, activity was doubled with glycine and Ala-Pro (both at $0.01 \%$ ); after $12 \mathrm{~h}$, Ala-Pro was still stimulatory but the monomers alanine and glycine gave the greatest increased production, which was $2-2 \cdot 7$ fold over controls.

Absence of even basal PR 1 activity after $4 \mathrm{~h}$ with Ala-Ala, Ala-Ala-Ala, Ala-Pro and Pro-Ala when supplied at $0 \cdot 1 \%$ probably resulted from catabolite repression because (i) basal synthesis of PR1 is regulated by derepression; (ii) the effect was no longer evident by $12 \mathrm{~h}$; (iii) lower concentrations (restricted supply or $0.01 \%$ ) gave activities similar to controls; and (iv) the peptides were not acting as competitive inhibitors of PR1, as revealed by a $30 \mathrm{~min}$ preincubation of pure PR1 with these peptides at $0.1 \%$ and $0.01 \%$ before assay (data not shown).

\section{DISCUSSION}

We have shown previously that PR1 is specifically induced by insect cuticle (Paterson et al., 1994). The component of insect cuticle which induces PR1 appears to be cuticular protein (or peptides thereof), as shown by (i) reduced PR1 levels in cultures grown on deproteinized cuticle, (ii) other cuticle components (i.e. chitin and lipids) having no effect on induction, and (iii) the induction of PR1 by peptides released from cuticle by pure preparations of PR1 and PR2.

The products of cuticle digestion released by pure preparations of either PR1 or PR2 were capable of inducing PR1 production when added to derepressed mycelium, but compounds solubilized by buffer were relatively ineffective, which demonstrates that an enzymically released peptide(s) of cuticular protein is the inducing molecule(s). Induction is therefore likely to result from the action of PR1 and PR2 produced at basal levels, which convert cuticle proteins to oligopeptide inducers.

The first proteinaceous barrier that the invading fungus encounters is the epicuticle. The nature of the proteins in this region is not known for any insect. However, epicuticular protein constitutes only a very small fraction of the total cuticular protein and if induction plays a significant role in regulating PR1 during infection it seems likely that peptide components of proteins in the main body of the cuticle are the effectors. The extreme $\mathrm{N}$ terminal regions of all but one of the 15 Locusta migratoria cuticle proteins which have been sequenced (Hojrup et al., 1986a, b; Klarskov et al., 1989; Andersen et al., 1993) are rich in glycine and large stretches of the remainder of the cuticle contain repetitive sequences dominated by alanine. Thus, for example in 'protein 38' from L. migratoria AlaAla-Ala is found six times, Ala-Ala-Pro-Ala ten times and
Ala-Ala-Pro-Val six times (Hojrup et al., 1986b); these repeated sequences constitute about $70 \%$ of the entire sequence.

It is possible that the inducer(s) of PR1 released from cuticle is in some way related to the preferred cleavage sites of either PR1 or PR2. The best substrate of PR1 is succinyl-(Ala) ${ }_{3}$-Phe-NA, although the substrates succinyl(Ala) ${ }_{2}$-Pro-Ala-NA, succinyl-(Ala) $)_{2}$-Pro-Phe-NA and acetyl-(Ala) ${ }_{3}$-NA are also readily hydrolysed (St Leger $e t$ al., 1987a). These substrates bear a striking resemblance to the repetitive peptides seen in locust cuticle, which would be excellent substrates for PR1, containing many cleavage sites. The action of basal levels of PR1 on cuticle would therefore release many peptides rich in alanine which could hypothetically induce further PR1 production. Whereas many fungal proteases have a broad specificity, PR2 has a primary specificity for arginine and lysine comparable to that of bovine trypsin (St Leger et al., 1987a). There are no obvious cleavage sites for PR2 in the repetitive sequences in locust cuticle, which contains only about $5 \%$ lysine and arginine (St Leger et al., 1986). However, presumably cuticle degradation by PR2 would also release peptides rich in alanine because alanine is the predominant amino acid in locust cuticle (St Leger et al., 1986).

Alanine di- and tripeptides, but not alanine or glycine, caused severe metabolite/catabolite repression of PR 1 production (Table 3), which indicates a system of uptake and/or catabolism of these peptides which is more efficient than that for the constituent monomeric amino acids; this would seem to reveal a further adaptation by this insect pathogen to host cuticular proteins, but even at low levels these peptides did not induce PR1. Analogously, facilitated utilization of the disaccharide cellobiose compared with glucose was reported for the cellulolytic plant pathogen Verticillium albo-atrum by Gupta \& Heale (1971), but in this case cellobiose is the inducer of cellulase.

Some peptides enhanced PR1 levels substantially (up to 2fold) above basal synthesis but the greatest effect (up to $2 \cdot 7$-fold) was observed with monomeric alanine and glycine (Table 3 ). However, these activities were always less than that achieved on cuticle, where about $6-9$-fold induction occurs after $12 \mathrm{~h}$ (Table 3 and Paterson et al., 1994). Nevertheless in most studies on induction of depolymerases it has been difficult to achieve enzyme production as high as that obtained using a polymeric $\mathrm{C}$ source by supplying a pulse of a putative inducer (Cooper \& Wood, 1975; Lerner \& Goldman, 1993; Woloshuk \& Kolattukudy, 1986); presumably this reflects the difficulty of achieving balance between nutrition, induction and derepression.

Cuticle digests were, however, effective in inducing high PR1 production when added at levels of amino acids similar to those in cultures where potential inducers were supplied from diffusion capsules. It would appear that we have yet to identify the true effector(s). The stimulatory effect on PR1 production of some of these cuticular peptides and amino acids remain unexplained. 
Induction of depolymerases by monomers is known for many polysaccharidases (Cooper, 1977) but it is difficult to reconcile the enhancement of PR 1 by monomeric glycine and alanine (Table 3 ) with the specificity of PR1 induction by insect cuticle but not by other proteins which also contain these amino acids. Also, preliminary data from size fractionations of enzyme-digested cuticular peptides suggested that the inducer(s) is larger than $200 \mathrm{Da}$. Recent evidence from Candida albicans indicates that induction of an extracellular aspartyl protease is effected by peptides of more than eight residues even though its permeases do not efficiently transport peptides $>6-7$ residues (Lerner \& Goldman, 1993). It is possible that a similar mechanism of peptide-initiated signal transduction occurs in $M$. anisopliae.

Whilst we have observed induction of PR1 by locust cuticle and enzymically solubilized peptides from locus: cuticle, we have not yet determined if induction occurs by exposure to cuticle from other insects. All isolates of $M$. anisopliae that we have investigated (about 40) produce a PR1-like enzyme (unpublished results; St Leger et al., 1987 c) and isolates of Metarbizium are pathogenic for insects from a number of orders including Orthoptera, Lepidoptera, Coleoptera and Diptera. Some sequences are available for cuticular proteins from two species of Lepidoptera [Manduca sexta (Rebers \& Riddiford, 1988) and Hyalophora cercopia (Willis, 1987)] and two species of Diptera [Drosopbila melanogaster (Snyder et al., 1982) and Sarcophaga bullata (Henzel et al., 1985)]. While there is some sequence homology between these proteins and the one protein sequenced from adult locust endocuticle (Talbo et al., 1991) they differ markedly from the locust exocuticle proteins described above. It remains possible, therefore, that PR1 induction only occurs during infection of certain insect hosts, namely those whose cuticular protein(s) contain the inducer molecule(s), and that another of the several proteases of $M$. anisopliae plays the key role in infection of different hosts. Alternatively, it is possible that induction by locust cuticle is some property of endocuticular rather than exocuticular protein.

It is remarkable that the effector molecule(s) responsible for induction of any microbial protease has yet to be identified. This may be because induction is effected by many different proteins, as in the case of the trypsin-like serine protease, PR2, from $M$. anisopliae (Paterson et al., 1993) and the aspartic protease from Mucor miehei (Lasure, 1980). In contrast, the specificity of PR1 induction by insect cuticular protein should facilitate our ongoing search for the inducers.

\section{REFERENCES}

Andersen, S. O. (1979). Biochemistry of insect cuticle. Annu Rev Entomol 24, 29-61.

Andersen, S. O. (1988). Comparison between cuticular proteins from two locust species, Locusta migratoria and Schistocerca gregaria. Insect Biochem 18, 751-760.

Andersen, J. S., Andersen, S. O., Hojrup, P. \& Roepstrorff, P. (1993). Primary structure of a $14 \mathrm{kDa}$ basic structural protein (Lm76) from the cuticle of the migratory locust Locusta migratoria. Invertebr Biochem Mol Biol 23, 391-402.
Charnley, A. K. (1984). Physiological aspects of destructive pathogenesis in insects by fungi: a speculative review. In Invertebrate Microbial Interactions, pp. 229-270. Edited by J. M. Anderson, A. D. M. Rayner \& D. W. H. Walton, British Mycological Society Symposium, vol. 6. London: Cambridge University Press.

Charnley, A. K. \& St Leger, R. J. (1991). The role of cuticledegrading enzymes in fungal pathogenesis of insects. In The Fungal Spore in Disease Initiation in Plants and Animals, pp. 267-287. Edited by G. T. Cole \& H. C. Hoch. New York \& London: Plenum Press.

Cole, S. C. J., Charnley, A. K. \& Cooper, R. M. (1993). Purification and partial characterisation of a novel trypsin-like cysteine protease from Metarbizium anisopliae. FEMS Microbiol Lett 113, 189-196.

Cooper, R. M. (1977). Regulation of synthesis of cell wall-degrading enzymes of plant pathogens. In Cell Wall Biochemistry Related to Specificity in Host Plant Interactions, pp. 163-211. Edited by B. Solheim \& J. Raa. Oslo: Universitetsforlaget.

Cooper, R. M. \& Wood, R. K. S. (1975). Regulation of synthesis of cell wall-degrading enzymes by Verticillium albo-atrum and Fusarium oxysporum f. sp. lycopersici. Physiol Plant Patbol 5, 135-156.

Gilby, A. R. (1980). Chemical methods (lipids). In Cuticle Techniques in Artbropods, pp. 217-252. Edited by T. A. Miller. SpringerVerlag: New York.

Grosscurt, A. C. (1978). Effects of difluorbenzuron on mechanical penetrability, chitin formation and structure of the elytra of Leptinotarsa decemlineata. J Insect Physiol 24, 827-831.

Gupta, D. P. \& Heale, J. B. (1971). Induction of cellulase (Cx) in Verticillium aibo-atrum. J Gen Microbiol 63, 163-173.

Henzel, W. J., Mole, J. E., Mulligan, K. \& Lipke, H. (1985). Sarcophagid larval proteins: partial sequence homologies among three cuticle proteins and related structures of Drosophilids. $J$ Mol Evol 22, 39-45.

Hojrup, P., Andersen, S. O. \& Roepstrorff, P. (1986a). Isolation, characterisation and $\mathrm{N}$-terminal sequence studies of cuticular proteins from the migratory locust, Locusta migratoria. Eur J Biochem 154, 153-159.

Hojrup, P., Andersen, S. O. \& Roepstrorff, P. (1986b). Primary structure of a structural protein from the cuticle of the migratory locust, Locusta migratoria. Biochem J 236, 713-720.

Klarskov, K., Hojrup, P., Andersen, S. O. \& Roepstrorff, P. (1989). Plasma-desorption mass spectrometry as an aid in protein sequence determination - application of the method on a cuticular protein from the migratory locust, Locusta migratoria. Biochem I 262, 923-930.

Lasure, L. L. (1980). Regulation of extracellular acid protease in Mucor miebei. Mycologia 72, 483-492.

Lerner, C. G. \& Goldman, R. C. (1993). Stimuli that induce production of Candida albicans extracellular aspartyl proteinase. $J$ Gen Microbiol 139, 1643-1651.

Moore, S. \& Stein, W. H. (1948). Photometric ninhydrin method for use in the chromatography of amino acids. J Biol Chem 76, 367-388.

Paterson, I. C., Charnley, A. K., Cooper, R. M. \& Clarkson, J. M. (1993). Regulation of production of a trypsin-like protease by the insect pathogenic fungus Metarbizium anisopliae. FEMS Microbiol Lett 109, 323-328.

Paterson, I. C., Charnley, A. K., Cooper, R. M. \& Clarkson, J. M. (1994). Specific induction of a cuticle-degrading protease of the insect pathogenic fungus Metarbizium anisopliae. Microbiology 140 , 185-189.

Pirt, S. J. (1971). The diffusion capsule, a novel device for the addition of a solute at a constant rate to a liquid medium. Biocbem $J$ 121, 293-297. 
Rebers, J. E. \& Riddiford, L. M. (1988). Structure and expression of a Manduca sexta larval cuticle gene homologous to Drosopbila genes. J Mol Biol 203, 411-423.

Snyder, M., Hunkapillar, M., Yeun, D., Silvert, D. J., Fristrom, J. W. \& Davidson, N. (1982). Cuticle protein genes of Drosophila: structure, organisation and evolution of four clustered genes. Cell 29, 1027-1040.

St Leger, R. J., Cooper, R. M. \& Charnley, A. K. (1986). Cuticledegrading enzymes of entomopathogenic fungi: cuticle degradation in vitro by enzymes from entomopathogens. I Invertebr Patbol 47, 167-177.

St Leger, R. J., Charnley, A. K. \& Cooper, R. M. (1987a). Characterisation of cuticle-degrading proteases produced by the entomopathogen Metarbizium anisopliae. Arch Biochem Biophys 253, 221-232.

St Leger, R. J., Cooper, R. M. \& Charnley, A. K. (1987b). Production of cuticle-degrading enzymes by the entomopathogen Metarbizium anisopliae during infection of cuticles from Calliphora vomitoria and Manduca sexta. J Gen Microbiol 133, 1371-1382.

St Leger, R. J., Cooper, R. M. \& Charnley, A. K. (1987c). Distribution of chymoelastases and trypsin-like enzymes in five species of entomopathogenic Deuteromycetes. Arch Biochem Biopbys 258, 123-131.
St Leger, R. J., Durrands, P. K., Charnley, A. K. \& Cooper, R. M. (1988a). Role of extracellular chymoelastase on the virulence of Metarbizium anisopliae for Manduca sexta. I Invertebr Pathol 52, 285-293.

St Leger, R. J., Durrands, P. K., Cooper, R. M. \& Charnley, A. K. (1988b). Regulation of production of proteolytic enzymes by the entomopathogenic fungus Metarbizium anisopliae. Arch Microbiol 150, 413-416.

Talbo, G., Hojrup, P., Rahbek-Nielson, H., Andersen, S. O. \& Roepstrorff, P. (1991). Determination of the covalent structure of an $\mathrm{N}$ - and $\mathrm{C}$-terminally blocked glycoprotein from the endocuticle of Locusta migratoria. Eur J Biochem 195, 495-504.

Woloshuk, C. P. \& Kolattukudy, P. E. (1986). Mechanism by which contact with plant cuticle triggers cutinase gene expression in the spores of Fusarium solani f.sp. pisi. Proc Natl Acad Sci US A 83, 1704-1708.

Weldon, C. \& Kefatos, F. C. (1980). Structure, organisation and evolution of developmentally regulated chorion genes in a silkmoth. Cell 22, 855-867.

Willis, J. H. (1987). Cuticular proteins: the neglected component. Arch Insect Biochem Physiol 6, 203-215.

Received 11 March 1994; revised 18 July 1994; accepted 3 August 1994. 